Southern Illinois University Carbondale

OpenSIUC

Publications

Fisheries and Illinois Aquaculture Center

$10-1974$

\title{
Use of a Sudden Temperature Decrease to Reduce the Excitability of Channel Catfish During Handling
}

William K. Anderson

Southern Illinois University Carbondale

William M. Lewis

Southern Illinois University Carbondale

Follow this and additional works at: http://opensiuc.lib.siu.edu/fiaq pubs

(c) by the American Fisheries Society 1974

Published in The Progressive Fish-Culturist, Vol. 36, Issue 4 (October 1974) at doi: 10.1577/

1548-8659(1974)36[213:UOASTD]2.0.CO;2

\section{Recommended Citation}

Anderson, William K. and Lewis, William M. "Use of a Sudden Temperature Decrease to Reduce the Excitability of Channel Catfish During Handling." (Oct 1974).

This Article is brought to you for free and open access by the Fisheries and Illinois Aquaculture Center at OpenSIUC. It has been accepted for inclusion in Publications by an authorized administrator of OpenSIUC. For more information, please contact opensiuc@lib.siu.edu. 


\title{
USE OF A SUDDEN TEMPERATURE DECREASE TO REDUCE THE EXCITABILITY OF CHANNEL CATFISH DURING HANDLING
}

\author{
William K. Anderson and William M. Lewis \\ Fisheries Research Laboratory and Department of Zoology \\ Southern Illinois University, Carbondale, Illinois 62901
}

HARVESTING AND SUBSEQUENTLY HANDLING fishes at water temperatures of approximately $80^{\circ} \mathrm{F}$ or greater often results in mechanical damage, physiological stress, and mortality. Yet the sale of channel catfish to be used in pay-fishing, and the sale of bait minnows, requires harvesting and handling in midsummer. Harry [1] reported using "thermal shock" to reduce mortality of golden shiners (Notemigonus crysoleucas) when they are harvested and handled at high temperatures. He advocated moving fish from the warmwater pond directly to $60^{\circ} \mathrm{F}$ water on the harvest truck. However, he pointed out that when moving fish from the hauling tank to holding tanks with higher temperatures, it is necessary to temper the fish at a rate not greater than $10^{\circ} \mathrm{F}$ per hour.

We have examined the effects on channel catfish (Ictalurus punctatus) of the instantaneous temperature change of $80^{\circ}$ to $60^{\circ} \mathrm{F}\left(26.6^{\circ}\right.$ to $\left.15.5^{\circ} \mathrm{C}\right)$, maintained for periods of 1 to 8 hours, followed by instantaneous return of the fish to $80^{\circ} \mathrm{F}$ water. The objectives were to determine if the channel catfish would tolerate these instantaneous temperature changes, and if this procedure could be used to reduce excitability, with a resulting reduction of physiological stress and mechanical damage.

NOTE.-This paper is based on a research report submitted by William K. Anderson to the Graduate Faculty of Southern Illinois University in 1973 in partial fulfillment of the requirements for the Master of Science Degree. The study was supported by Southern Illinois University.

Mr. Anderson's present address is Mississippi Game and Fish Commission, Division of Fisheries, P.O. Box 451, Jackson, Miss. 39205.

VOL. 36, NO. 4, OCTOBER 1974

\section{MATERIALS AND METHODS}

Three procedures were used to evaluate the effects of sudden temperature change. In the first procedure, yearling channel catfish (18.0 to 170 grams, mean 60.5) were acclimated to aquarium conditions at $80^{\circ} \mathrm{F}\left( \pm 3^{\circ}\right)$. The fish were then moved by dip nets to adjacent tanks containing $60^{\circ} \mathrm{F}$ water $\left( \pm 2^{\circ}\right)$, held there for 1 to 8 hours, and returned without acclimating to $80^{\circ} \mathrm{F}$ water. To demonstrate the effects of handling, fish were also moved from $80^{\circ}$ to $80^{\circ} \mathrm{F}$ water. The effects of the temperature change were evaluated by observing for evidence of abnormal behavior and mortality for a period of 10 days after the fish were transferred.

The second procedure consisted of measuring oxygen consumption of fish transferred from $80^{\circ}$ to $60^{\circ} \mathrm{F}$ water, as compared to that of fish transferred from $80^{\circ}$ to $80^{\circ} \mathrm{F}$ water. Oxygen consumption was measured with a constant head respirometer, using 8 experimental fish and 8 control fish (35.0 grams, \pm 1.5 ). Oxygen consumption was determined at 10-minute intervals for 8 hours. The mean values of consumption for the two treatments were compared, using a modified two-way analysis of variance [2].

The third procedure consisted of actual hauling trials ranging in length from 1 to 4 hours. Fish were seined from a pond and transported in a fiberglass hauling tank mounted on a pickup truck. Water temperatures of the ponds from which the fish were harvested ranged from $83^{\circ}$ to $86^{\circ} \mathrm{F}$. By using ice, the water temperature of the hauling tank was maintained $20^{\circ} \mathrm{F}$ below the temperature of the pond from which the fish were taken. After being hauled, the fish were placed either in aquariums or in clear- 
water ponds free of other fish. Mortality occurring during a 10-day period after hauling was recorded.

\section{RESULTS}

When fish were transferred from $80^{\circ}$ to $60^{\circ} \mathrm{F}$ water and held from 1 to 8 hours, no mortality attributable to the transfer occurred during the 10-day observation period following (table 1). Both experimental and control fish fed the day following the transfer, with one exception. One lot of experimental fish exposed to $60^{\circ} \mathrm{F}$ for 6 hours did not feed until the second day following transfer back to the warm water. The experimental fish exhibited a fairly predictable behavior pattern. Following introduction into the $60^{\circ} \mathrm{F}$ water, the fish swam slowly around the aquarium for about 5 minutes, then settled to the bottom and lay still for 45 to 60 minutes, after which they became more active, alternately swimming slowly and lying still for the duration of the exposure to the $60^{\circ} \mathrm{F}$ water. Activity tended to increase with the length of time the fish were held at $60^{\circ} \mathrm{F}$, but they were always less active and less excitable than the control fish. Less than 5 minutes after they were returned to $80^{\circ} \mathrm{F}$ water, the experimental fish commenced to exhibit behavior identical to that of the control fish.

Table 1.-Mortality of channel catfish exposed to the sudden temperature change from $80^{\circ}$ to $60^{\circ} \mathrm{F}$ followed by immediate return to $80^{\circ} \mathrm{F}$

\begin{tabular}{|c|c|c|c|}
\hline & $\begin{array}{c}\text { Hours held } \\
\text { at } 60^{\circ} \mathrm{F}\end{array}$ & $\begin{array}{c}\text { Number } \\
\text { of fish }\end{array}$ & $\begin{array}{l}\text { Mortality } \\
\text { (numbers) }\end{array}$ \\
\hline 1 & $\ldots \ldots \ldots$ & 60 & 0 \\
\hline 2 & $\ldots \ldots \ldots \ldots \ldots \ldots \ldots \ldots \ldots$ & 70 & 0 \\
\hline 4 & $\ldots \ldots \ldots \ldots \ldots \ldots \ldots \ldots \ldots$ & 75 & 0 \\
\hline 6 & $\ldots \ldots \ldots \ldots \ldots \ldots \ldots \ldots \ldots$ & 113 & 1 \\
\hline 8 & $\ldots \ldots \ldots \ldots \ldots \ldots \ldots \ldots \ldots$ & 240 & 2 \\
\hline & (control) $\ldots \ldots \ldots \ldots \ldots \ldots \ldots$ & 151 & 1 \\
\hline
\end{tabular}

Fish transferred from $80^{\circ}$ to $50^{\circ} \mathrm{F}$ or cooler water exhibited an initially violent reaction for the first few minutes. They convulsed violently and attempted to leap out of the water. Some swam upside down or on their sides, then sank to the bottom and lay on their sides or backs. The majority of the fish lost their equilibrium. After extended exposure to the low temperature, a few fish regained their equilibrium, but all remained lying on the bottom and exhibited no activity (table 2 ). When returned to $80^{\circ} \mathrm{F}$
Table 2.-Mortality of channel catfish exposed to sudden temperature decreases from $80^{\circ}$ to $50^{\circ} \mathrm{F}$ or less followed by immediate return to $80^{\circ} \mathrm{F}$

\begin{tabular}{lcccc}
\hline $\begin{array}{c}\text { Temperature } \\
\text { Lowered to } \\
\left({ }^{\circ} \mathrm{F}\right)\end{array}$ & $\begin{array}{c}\text { Hours held } \\
\text { at lowered } \\
\text { temperature }\end{array}$ & $\begin{array}{c}\text { Number } \\
\text { of fish }\end{array}$ & $\begin{array}{c}\text { Mortality } \\
\text { (numbers) }\end{array}$ \\
\hline 50 & $\ldots \ldots \ldots \ldots \ldots$ & 1 & 52 & 0 \\
45 & $\ldots \ldots \ldots \ldots \ldots$ & 1 & 52 & 0 \\
45 & $\ldots \ldots \ldots \ldots \ldots$ & 2 & 52 & 0 \\
40 & $\ldots \ldots \ldots \ldots \ldots$ & 1 & 145 & 40 \\
Control $\ldots \ldots \ldots$ & 1 & 52 & 0 \\
\hline
\end{tabular}

water, the fish remained motionless on the bottom for 5 to 20 minutes before resuming activity. Of the 40 fish that died following the 1-hour exposure to $40^{\circ} \mathrm{F}$ water, 38 never resumed activity following exposure (table 2 ). They were apparently killed immediately by the temperature change. One fish died 5 days after the experiment, and another died 9 days afterwards.

In the hauling experiment, no mortality occurred when the fish were subjected to a $20^{\circ} \mathrm{F}$ change in temperature and transported for 1 to 4 hours (table $3)$.

Table 3.-Mortality of channel catfish exposed to the sudden temperature decrease of $20^{\circ} \mathrm{F}$ in actual bauling trials followed by immediate return to the original temperature

\begin{tabular}{ccccc}
\hline $\begin{array}{c}\text { Temperature } \\
\text { change } \\
\left({ }^{\circ} \mathrm{F}\right)\end{array}$ & $\begin{array}{c}\text { Hours held } \\
\text { at lowered } \\
\text { temperature }\end{array}$ & $\begin{array}{c}\text { Approximate } \\
\text { number } \\
\text { of fish }\end{array}$ & $\begin{array}{c}\text { Mortality } \\
\text { (numbers) }\end{array}$ \\
\hline $86-66$ & $\ldots \ldots \ldots$ & 1.00 & 200 & 0 \\
$86-66$ & $\ldots \ldots \ldots$ & 3.25 & 450 & 0 \\
$83-63$ & $\ldots \ldots \ldots$ & 4.00 & 240 & 0 \\
$83-63$ & $\ldots \ldots \ldots$ & 4.00 & 290 & 1 \\
\hline
\end{tabular}

Oxygen consumption of the control fish was much higher than that of the experimental fish immediately after handling, and remained higher during the following 8-hour period (fig. 1). The difference between the two treatments was statistically significant at the 0.05 level. After being returned to $80^{\circ} \mathrm{F}$ water following an 8 -hour exposure to $60^{\circ} \mathrm{F}$ water for the experimental fish and $80^{\circ} \mathrm{F}$ water for the controls, oxygen consumption by the fish was highly variable (fig. 2 ).

THE PROGRESSIVE FISH-CULTURIST 


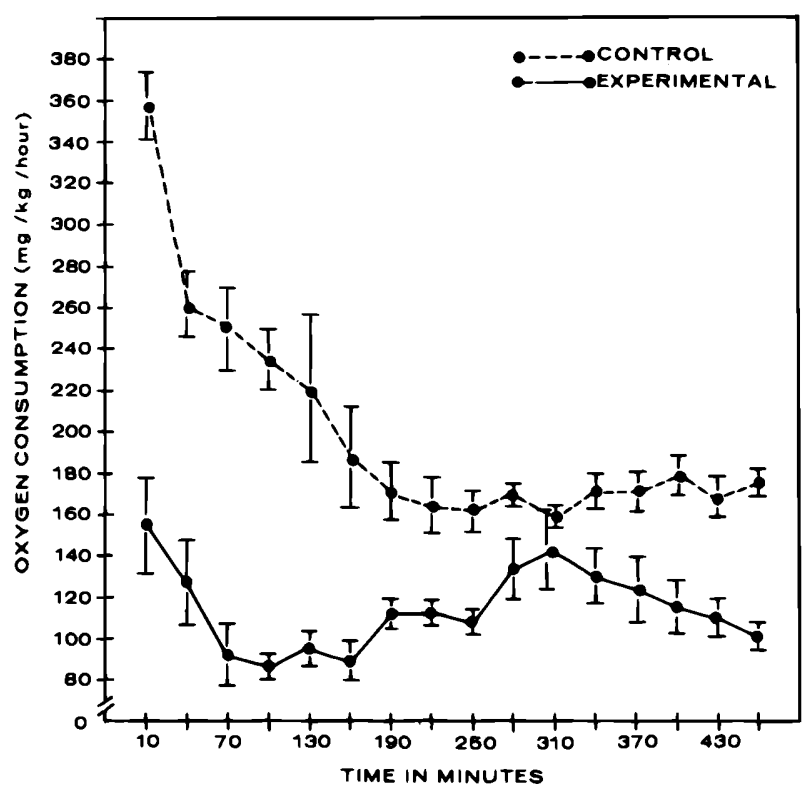

Figure 1.-Mean oxygen consumption of eight channel catfish transferred from $80^{\circ}$ to $80^{\circ} \mathrm{F}$ water (control) vs. eight channel catfish transferred from $80^{\circ}$ to $60^{\circ} \mathrm{F}$ water (experimental).

\section{CONCLUSIONS}

The excitability of yearling channel catfish can be successfully controlled by instantaneous transfer of the fish from $80^{\circ}$ to $60^{\circ} \mathrm{F}$ water. Following transfer, the fish can be held at the lower temperature for at least 8 hours and not exhibit noticeable effects when they are transferred back to the higher temperature. Tempering is not necessary when the fish are returned to $80^{\circ} \mathrm{F}$ water. This technique can be successfully applied to harvesting and handling channel

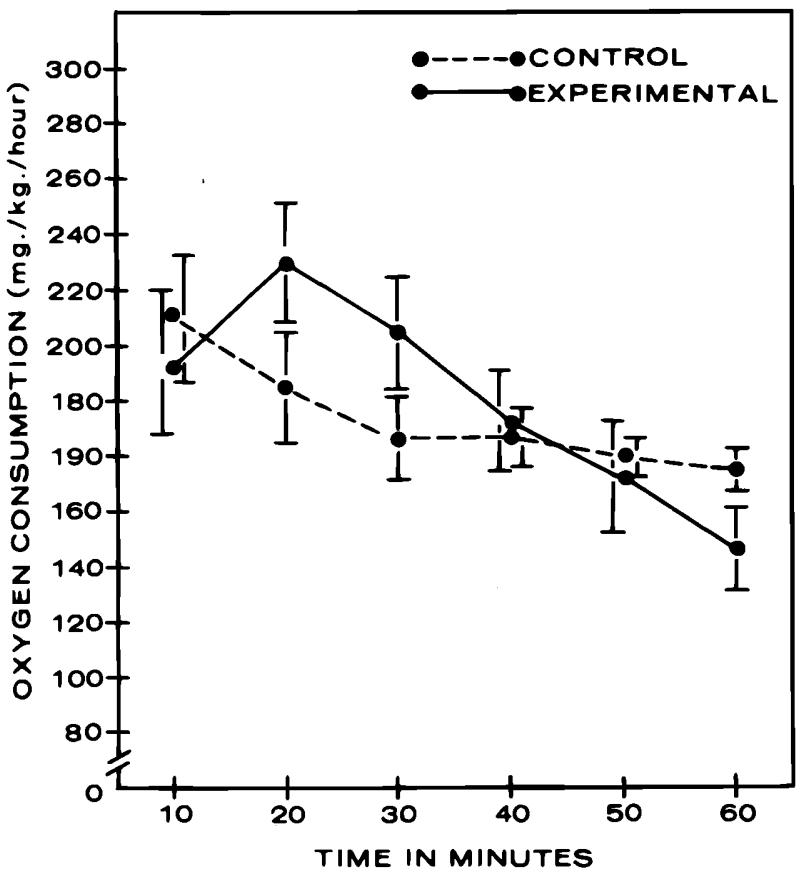

Figure 2.-Mean oxygen consumption of eight control and eight experimental channel catfish returned to $80^{\circ} \mathrm{F}$ water following 8-hour exposures to control $\left(80^{\circ} \mathrm{F}\right)$ and experimental $\left(60^{\circ} \mathrm{F}\right)$ temperatures.

catfish when pond water temperature is unfavorably high.

\section{REFERENCES}

1. HARRY, GEORGE V.

1968. Handling and transporting golden shiner minnows. Pages 37-42 in Proceedings of the Commercial Bait Fish Conference, Texas A\&M University, College Station, Texas.

2. LINDQUIST, E. F.

1953. Design and analysis of experiments in psychology and education. Riverside Press, Cambridge, Mass. 393 p. 